\title{
POSITION AND ROLE OF THE AMBASSADORS ACCORDING TO VIENNA CONVENTION AND LAW ON FOREIGN AFFAIRS OF THE REPUBLIC OF MACEDONIA
}

\author{
Aneta Stojanovska-Stefanova*, Drasko Atanasoski** \& Katerina \\ Stojanovska***
}

The Vienna Convention on Diplomatic Relations, Consular Relations, Representation of states and their relations with international organizations of universal character, as well the Convention on Special Missions which codifies the modern diplomatic law, with its diverse, elastic solutions enabled the states to use combinations of numerous possibilities of collection of functions and offices, in the target of the rational use of its diplomatic-consular network and of the networks of other countries.

INTRODUCTION

I. Foreign Policy AND DEVELOPMENT OF Diplomatic RELATIONS OF THE

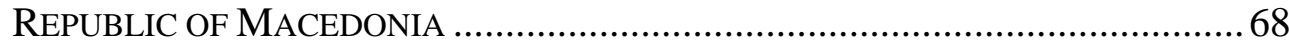
II. RESPONSIBILITIES OF THE AMBASSADORS IN ACCORDANCE WITH VIENNA CONVENTION AND THE LAW OF FOREIGN AFFAIRS OF THE REPUBLIC OF

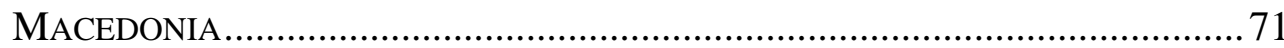

A. In Accordance with the Vienna Convention the Diplomatic Officers Enjoy the Following Rights and Obligations.... 71

B. Pursuant to the Law on Foreign Affairs ("Official Gazette of the Republic of Macedonia” No. 46/06 and 107/2008)...................................... 72

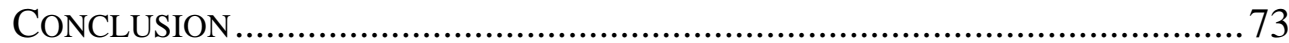

\section{INTRODUCTION}

Vienna Convention on Diplomatic Relations adopted in 1961, contributed a lot to culmination on diplomatic and consular functions, allowing the diplomatic missions to perform consular functions. In fact Article 3, paragraph 2 of the Convention provides that: "Nothing in the

\footnotetext{
* Aneta Stojanovska-Stefanova, PhD candidate, teaching assistant, Faculty of Tourism and Business Logistics, University Goce Delcev, Republic of Macedonia. Research fields: International Law and Politics, History of Diplomacy, Political Systems.

** Drasko Atanasoski, Ph.D., assistant professor, Faculty of Tourism and Business Logistics, University Goce Delcev, Republic of Macedonia. Research fields: International Transport and Logistics, Customs Administrative Procedure.

*** Katerina Stojanovska, translator, MA candidate at University Goce Delcev, Republic of Macedonia. Research fields: English Language and Translation, Sociolinguistics.
} 
present Convention shall be construed as preventing the performance of consular functions by a diplomatic mission”. This provision fills the Vienna Convention on Consular Relations, adopted in 1963, which in Article 3 specifically stipulates that: "consular functions can perform the diplomatic missions in accordance with the provisions of this Convention". In the Article 70 of the Convention states that, its provisions "the provisions of the present Convention apply also, so far as the context permits, to the exercise of consular functions by a diplomatic mission" and that, the names of the members of diplomatic missions which are designated for consular departments of the mission or are otherwise certain to perform consular functions, will be appointed by the Ministry of Foreign Affairs of the receiving State or by other authority that will be determined by the relevant ministry. With the same article of the Vienna Convention on Consular Relations, is finally solved one practical question about the status of the members of the diplomatic missions who perform consular functions, which over the years has been the subject not only of academic discourse, but also of serious different opinions in the proceeding of codification of the diplomatic law: if those persons have the right of privileges and immunities as members of diplomatic missions, i.e. according to the rules of the Vienna Convention on diplomatic relations or as members of consular relations. After a series of serious discussions of the Vienna Convention on Consular Relations, it is adopted that, privileges and immunities of the members of diplomatic missions who perform consular functions stipulated in compliance with the Vienna Convention on Diplomatic relationships for performing of consular functions such persons do not lose the privileges and immunities as members of diplomatic missions, by which finally an end is put to the views of individual countries that the performing of consular functions by members of diplomatic missions is related to the denial of the diplomatic status and their deepening by the status consulate members, with extremely reduced privileges and immunities.

\section{Foreign Policy AND DEVELOPMENT OF Diplomatic RELATIONS OF THE REPUBLIC OF MACEDONIA}

Republic of Macedonia promotes its national values and interests through foreign policy-on bilateral and multilateral plan. European and Trans-Atlantic integration is a vital interest for long-term stability, security and prosperity of the Republic of Macedonia. The Republic of Macedonia is committed to fulfillment of five foreign-policy priorities: NATO membership and a date for the beginning accession negotiations for full 
membership in the European Union, abolition of visas for Macedonian citizens, overcoming of the issue of the name difference imposed by our southern neighbor and reinforcement of the economic and public diplomacy. Republic of Macedonia has fulfilled all the criteria for NATO membership and has implemented the necessary reforms. In the declaration of the NATO Summit in Bucharest, our commitment to the values and operational activities of NATO and the progress in the reform process was clearly acknowledged. Due to the opposition of the Republic of Greece, the invitation for NATO membership, the Alliance will send after finding a mutually acceptable solution to the issue about the difference over the name of the Republic of Macedonia, for which talks have been holding under the auspices of the United Nations. The membership of the Republic of Macedonia in NATO will mean long-term stability and security not only for the Balkans but for the Euro-Atlantic region as a whole and the beginning of the finalization of the concept of a Europe, whole, free and at peace. In the relations with the European Union, the main commitment of the Republic of Macedonia is to start negotiations for accessions as soon as possible and to this end the Government and state institutions work devotedly to the fulfillment of the priorities of the Accession Partnership from 2008. We expect that, during 2009, our efforts and achievements to be evaluated by European Commission recommendation to start accession negotiations, followed by appropriate decision by the European Council. The Republic of Macedonia expects early and successful termination of the dialogue on visa regime liberalization with the European Union. In relation to the established significant progress in meeting of the conditions of the Roadmap for visa liberalization, we expect at the beginning of 2009, from the European Commission to initiate a legal proceeding in the Council of EU to lift the visa regime for Macedonia and the entry into force of the visa-free regime during 2009. Republic of Macedonia participates constructively and actively in the negotiation process under the auspices of the Special Representative of the UN Secretary-General, Ambassador Matthew Nimetz to overcome the irrational issue imposed by the Republic of Greece concerning the difference about the name of our country. Republic of Macedonia is continuously engaged in finding a mutually acceptable solution that would not infringe on the Macedonian national identity, language and culture. Republic of Macedonia is committed to continuously strengthening of the strategic partnership with the United States and developing of comprehensive partnership relations with member states of the EU and NATO, whereupon pays particular attention to the relations and cooperation with other important actors on the international stage, primarily with the 
Russian Federation and the People's Republic of China. In the relations and cooperation with the neighboring countries, a good-neighborliness and friendship and readiness for comprehensive cooperation in many areas of mutual interest is promoted. Good neighborly relations as one of the priorities in the foreign policy represent original determination, an instrument for enhancing of the mutual trust and simultaneously, a complementary factor on the accession road of the Republic of Macedonia towards EU and NATO. Establishing of comprehensive cooperative relations with all countries in the immediate and wider neighborhood-both at bilateral plan and within regional initiatives and projects through participation in the existing initiatives for regional cooperation in the entire region of South East Europe, represents an active contribution of the Republic of Macedonia in the creation of relations of security, stability and cooperation in Southeast Europe. Republic of Macedonia is continuously engaged in promoting and further enrichment of the relations with democratically committed countries with which it has to great extent traditionally good and developed relations. Republic of Macedonia actively participates in the work of all relevant international organizations, as in global level-UN and of specialized agencies, WTO, and in regional organizations - OSCE, Council of Europe etc., as the most effective way of protecting of the world peace and security from the global threats of nowadays: terrorism, proliferation of weapons of mass destruction, organized crime, the preservation of a healthy environment, dealing with economic and social issues (non-) respect for human rights and more. The promotion of economic potentials and investment opportunities in the Republic of Macedonia, as well the development of active external economic policy is aimed at intensifying and qualitative enhancement of the bilateral economic relations with the countries of the region, Europe and the entire international community. On the basis of the importance of the national identity and values of the Macedonian people for the sovereignty, independence and security of the state, the Republic of Macedonia attaches great importance to the promotion of the national, cultural and spiritual identity outside the borders of the Republic of Macedonia. Concern for the position of the Macedonian communities living outside the national boundaries and for improvement of the legal status, and treatment of the Macedonian national minority in other countries, according to the international treaties and the concluded bilateral treaties and agreements, represents one of the most important foreign policy goals. Republic of Macedonia participates in peacekeeping missions (UN, NATO, EU) in support of peace, security and stability. Presently, Macedonia contributes 
with about 240 people in international operations or about $3.5 \%$ of its own military forces. Republic of Macedonia participated with its troops in Afghanistan (ISAF), Iraq (Iraqi Freedom), Bosnia and Herzegovina (ALTHEA) and Lebanon (UNIFIL), and also provides logistical support to KFOR in Kosovo. Regarding the participation in international missions led by NATO, Republic of Macedonia received the highest marks from NATO, which sees our country as a stable military partner to the Alliance ${ }^{1}$.

The process of recognition of the Republic of Macedonia started in 1992. Since then until today, diplomatic relations with 170 countries have been established. Our country has established diplomatic relations with about 170 countries worldwide, and under its constitutional name, is recognized by over 130 countries including three permanent members of the Security Council—USA, Russia and China. Republic of Macedonia before exactly 22 years ago became the 181st full member of the United Nations. This act confirmed the will of the Macedonian people after the referendum on September 8, 1991 for a sovereign and independent Macedonia. Because of the opposition and pressure from Greece, which does not accept our constitutional name, the registration in the world organization was made under the interim reference Former Yugoslav Republic of Macedonia ${ }^{2}$.

\section{RESPONSIBILITIES OF THE AMBASSADORS IN ACCORDANCE WITH VIENNA CONVENTION AND THE LAW OF FOREIGN AFFAIRS OF THE REPUBLIC OF MACEDONIA}

Vienna Convention on Diplomatic Relations from 1961, signed in Vienna on April 18, 1961 came into force on April 24, 1964.

A. In Accordance with the Vienna Convention the Diplomatic Officers Enjoy the Following Rights and Obligations

Free movement and travel throughout the territory of the receiving State;

Right of free communication with the Government of the sending state, through including diplomatic couriers and installing of wireless transmitters, but only with the consent of the receiving State;

The receiving State shall protect the diplomatic official in the performance of his function who possess an official document of his status;

\footnotetext{
${ }^{1}$ Available at http://www.mfa.gov.mk/default1.aspx?ItemID=263, Ministry of Foreign Affairs of the Republic of Macedonia, opened on July 27, 2012.

${ }^{2}$ Available at http://mrt.com.mk/node/22051, Macedonian Radio Television, opened on August 25, 2015.
} 
Diplomatic officials who possess an official document that confirms their status are not subject to any form of arrest or detention and the receiving State shall take all necessary measures to protect his person;

Shall guarantee inviolability of the private residence and protection of the premises of the mission;

Diplomatic officers enjoy immunity from criminal prosecution;

Immunity does not prevent the receiving State for his extradition to the sending State;

On the entry into the receiving State, the baggage of the diplomatic official and his family is exempt from inspection;

The diplomatic officials begin to use the privileges and immunities from the entrance to the receiving State until its abandonment;

In case of the death of a member of the mission, the members of his family shall continue to enjoy the privileges and immunities to which they are entitled until the expiry of a reasonable period in which to leave the country;

The diplomatic agent shall not in the receiving State practise for personal profit any professional or commercial activity;

The receiving State is obliged in case of armed conflict to protect the premises of the mission;

B. Pursuant to the Law on Foreign Affairs ("Official Gazette of the Republic of Macedonia” No. 46/06 and 107/2008)

According to Article 26 of the Law:

The Embassy and Liaison Office besides the functions stated in the Vienna Convention on Diplomatic Relations, perform the following functions:

Represent and plead the Republic of Macedonia in the receiving State;

Protects the interests of the Republic of Macedonia and its citizens and legal entities and perform consular and legal affairs;

Promotes and develops the relations and overall cooperation between the Republic of Macedonia and the receiving State for the interests of the Republic of Macedonia;

Participate in the negotiations with the government of the receiving State and other state institutions;

Monitor the internal and external position and activity of the receiving State and shall inform the Ministry about that, which forward the information to the President and;

Notify the authorities, institutions and public of the receiving State 
about the positions and the development of the Republic of Macedonia;

Monitor the current economic policy of the receiving State and regularly inform the Ministry that, forward information to the competent institutions in the Republic of Macedonia and;

Promote Republic of Macedonia on economic plan in the receiving State and present the opportunities and advantages of investing in coordination and cooperation with the economic promoters from the Republic of Macedonia located in the receiving State, with the Agency for Foreign Investments of the Republic of Macedonia and the ministers in charge of foreign investments.

Embassy and Liaison Office develop their work on political, economic, security, cultural, scientific-technical, informational and other field.

The Embassy and Liaison Office devote special care to the status and human rights of the Macedonian people in the neighboring countries and to the citizens of the Republic of Macedonia.

According to Article 35 of the Law:

The head of the diplomatic and consular missions shall perform the following duties:

Organize the work of the diplomatic and consular mission, classifies tasks and undertakes measures in relation to matters within the jurisdiction of the mission;

In accordance with the regulations takes care for the fulfillment of the rights and obligations of officers in the mission;

Decide for financial and material operations of the mission within the budget of diplomatic and consular missions and;

Perform other duties in accordance with the regulations and instructions of the Minister.

According to Article 48:

Besides the duties of diplomatic and consular officers stipulated in this law, the Ambassador shall be obliged to:

Act in accordance with the established foreign policy of the Republic of Macedonia;

Contributes to the strengthening of the relations with the receiving State or international organization and;

Manages with the mission in which he was appointed;

Act in accordance with the instructions and directions of the Minister.

CONCLUSION

The analysis of the activities of the holders of the foreign policy of the 
Republic of Macedonia indicates the conclusion that, in the process of exercising of its own foreign policy priorities, our country in the past years from its independence until today is guided by the fundamental tenets of the constitution, and the laws and principles of the activities in the states in the United Nations.

The objectives of the foreign policy of the Republic of Macedonia in the past years have been carried out by the office holders who were elected in free, fair and democratic elections, but they have remained substantially unchanged. However, in view of the characteristics of the individuals who carried out these functions over the years, differences are observable.

The development of democracy in the independent states that, were created after the fall of communism in Eastern Europe had a great influence on this, the approach in duty performance from the aspect of ideological and political profile and of course, the global changes taking place in the international community.

The Republic of Macedonia in the implementation of foreign policy is guided by the respect of the Charter of the United Nations, resolving conflicts, disputes and open-issues between the countries peacefully, adherence to the international and legal principle for invariability of the borders, respecting of the policy for promotion of the body on Human rights and freedoms, supporting of the disarmament efforts and ban on all weapons of mass destruction, support for the promotion of the international economic relations in conditions of economic globalization.

The Institute of International Recognition is one of the instruments for developing of the cooperation with other countries based on mutual interests. This institute "recognition of States" is known from the League of Nations and the United Nations. The legal effects of the recognition of states are limited if they are limited only to a declaratory act, but they can be both constitutive and more serious, if they are followed with the establishment of other legal and economic pressures, such as isolation or boycotts.

It is important to emphasize that, the recognition of the states has no direct connection with the establishment of diplomatic relations, namely it can happen the state to be recognized, but not to establish diplomatic relations with it, while the reverse is not possible, since the establishment of the diplomatic relations implies recognition of that country. 